... Župčić, Žulj, Kamerman, Grbac, Vlaović: Research into Corner L Separable Assemblies...

Ivica Župčić, Ivan Žulj, Igor Kamerman, Ivica Grbac, Zoran Vlaovićl

\title{
Research into Corner L Separable Assemblies in Storage Furniture
}

\section{Istraživanje rastavljivih kutnih L-sastava namještaja za odlaganje}

Preliminary paper • Prethodno priopćenje

Received-prispjelo: 11. 4. 2019.

Accepted-prihvaćeno: 14. 1. 2021.

UDK: $630 * 824.52 ; 630 * 836.2$

https://doi.org/10.5552/drvind.2021.1924
(C) 2021 by the author(s).

Licensee Faculty of Forestry, University of Zagreb.

This article is an open access article distributed under the terms and conditions of the

Creative Commons Attribution (CC BY 4.0) license.

\begin{abstract}
This research is based on the testing of the impact of the board (particleboard and medium density fiberboard $(M D F)$ ) and hardware type used to connect the sides and the bottom or top of the storage furniture on the joint strength. The hardwares of the following trade mark were used: the confirmat screw, Minifix, Maxifix, Stablofix, RV and Solo 32. Such hardwares make it possible to disassemble the furniture as well as to assemble it (when moving the furniture) without reducing joint strength when reassembling it due to wear and tear on the material (with the exception of the confirmant screw). Research results showed that assemblies with the Maxifix hardware installed in the MDF base exhibited the highest values of bending moment (the average bending moment of $85.88 \mathrm{Nm}$ ). On the other hand, assemblies with the Minifix hardware installed in the particleboard exhibited the lowest values of bending moment (over three times lower than the Maxifix) (the average bending moment of 24.50 $\mathrm{Nm}$ ). Assemblies with the confirmat screw exhibited satisfactory results, although, aesthetic requirements seem to be the main problem here (the average bending moment of $40.38 \mathrm{Nm}$ for the particleboard and of $64.24 \mathrm{Nm}$ for the MDF board).
\end{abstract}

Keywords: corner assembly; separable assemblies; hardware; fitting; storage furniture

SAŽETAK • Istraživanje se temelji na ispitivanju utjecaja vrste drvne ploče (iverice $i$ MDF ploče) i tipa okova koji služi za povezivanje stranice i poda ili stropa namještaja za odlaganje na čvrstoću kutnog spoja. Kao spojni okov rabljeni su oni trgovačkog naziva confirmat vijak, minifix, maxifix, stablofix, $R V$ i solo 32. Navedeni okov omogućuje rastavljanje $i$ sastavljanje namještaja (npr. prilikom selidbe namještaja) a da pri ponovnom sastavljanju ne bude narušena čvrstoća spoja zbog habanja materijala (izuzetak je confirmat vijak). Prema rezultatima istraživanja, najveće vrijednosti momenta savijanja zabilježene su u sastava s maxfix okovom ugrađenim u podlogu od MDF ploče (prosječni moment savijanja 85,88 Nm). Najmanje vrijednosti momenta savijanja (preko tri puta manje u usporedbi s maxifixom) izmjerene su za sastav s minifix okovom koji je ugrađen u ploču ivericu (prosječni je moment savijanja 25,40 Nm). Spojevi s confirmat vijkom pokazuju zadovoljavajuće rezultate momenta savijanja, ali su estetski zahtjevi glavni problem tog načina povezivanja elemenata (prosječni moment savijanja za troslojnu ploču ivericu iznosi 40,38 Nm, a prosječni je moment savijanja za MDF ploče 64,24 Nm).

Ključne riječi: kutno sastavljanje; rastavljivi sastavi; okov; vezni elementi; namještaj za odlaganje

\footnotetext{
${ }^{1}$ Authors are associate professor, senior assistant, student, professor and associate professor at University of Zagreb, Faculty of Forestry, Croatia.
} 


\section{INTRODUCTION}

\section{UVOD}

Storage furniture is everywhere around us and there is hardly a living quarter or business premises without it. Such furniture is usually of considerable dimensions so that it is desirable for such furniture to be reassemblable so that it may be easily transported and delivered to its user. It is designed for the storage of objects. It may be classified according to its place of use, dimensions, purpose, constituent material and technology, construction, historic style, etc. Storage furniture is most commonly constructed as cabinets of larger dimensions, so that the desirable construction is the one that makes it possible to assemble and disassemble the cabinet corpus at its end user's location. Therefore, this type of furniture should be connected with fittings. Assembling principles for the cabinet corpus are determined by corner plane $\mathrm{L}$ assemblies and the mutual position of the side and the middle side in relation to the bottom and the top. In case of larger cabinets, its back is an important part of its construction. The cabinet back is a plate element closing the corpus from the back side and maintaining the position of the corpus sides at right angles in relation to the bottom and the top. It has a big impact on construction strength and rigidity.

Yerlikayae (2012) tested the corner L joint for strength on specimens made of particleboard. The testing was done on five specimen types connected with five angled plane assembly types: butt joint reinforced with fiber-glass fabric, dowel joint, dowel joint reinforced with fiber-glass fabric, dowel joint with the Minifix hardware, dowel joint and the Minifix hardware reinforced with fiber-glass fabric. The results showed that the glass-fiber composite layer considerably enhances the strength of a joint, and that the increase is significantly higher under compressive load than under tensile load. Both types of test recorded the highest joint strength, i.e. for the dowel joint and for the Minifix hardware reinforced with glass-fiber fabric.

Atar and Ozcifci (2007) analyzed the impact of screws and dowels on the strength of the angled plane assembly. Materials used for the research were: solid beechwood, particleboard, medium density fiberboard (MDF) and wood core plywood. Elements used for assembling corner joints were dowels, screws and PVAc adhesive. The highest value of bending moment of 133.7 Nm was measured on the specimen made of $\mathrm{MDF}$, and the lowest of $111.0 \mathrm{Nm}$ on the specimen made of wood core plywood.

Vassiliou and Barboutis (2009) analyzed the static bending strength of the joint with hardwares of four manufacturers: Hettich, Germany; Häfelle, Germany; Lama, Slovenia and of an unknown manufacturer. As their results showed, static bending strength depends on the manufacturer, hardware type and the type of the material on which the hardware is applied. The results also showed that certain metal hardwares exhibit higher static bending strength values than the plastic ones. Furthermore, the research revealed that the hardware exhibits higher static bending strength values when ap- plied in the MDF (plastic hardware by $32.58 \%$, metal hardware by $35.72 \%$ ) than when applied in the particleboard.

Kurelia and Altinoka (2011) researched into mechanical properties of corner joints (in relation to pressure and tension) made of particleboard, fiberboard and particleboard reinforced with synthetic resins. Three testing types were carried out: testing the corner L joint for compressive strength, testing the corner L joint for tensile strength and testing the corner $\mathrm{T}$ joint for tensile strength. The Minifix system was used as the hardware in two versions, with plastic and metal housing. The results showed that the strongest joint was the one in the MDF connected with the metal or plastic Minifix system or in the improved MDF. This also leads to the conclusion that the board and hardware type influence joint strength and that, when making the construction joint, attention should be paid to the choice of the board and hardwares.

Jivkov and Grbac (2011) examined the impact of static and dynamic loading on the bending moment in the angled plane assembly. The specimens were made of $18 \mathrm{~mm}$ thick MDF and connected with the dowel, screw, confirmat screw and bolt with the turning pin (two types). The joints with the screw and the confirmat screw exhibited the best results. The joint with the dowel exhibited a $40 \%$ lower bending moment than the assembly with the screw. According to the authors, the assembly with the bolt with the turning pin exhibited the lowest bending moment as expected (80\% lower than the screw).

Ayrilmis and Akbulut (2018) analyzed the screw withdrawal resistance and the interlayer strength in fiberboards. The screw withdrawal resistance increases with the increase in the fiber length in the middle layer and the increase in the resin portion in the middle layer, with the increase in the surface/middle layer ratio and the increase in the board density.

Smardzewski and Ożarska (2005) examined the mathematical model of the rigid composition with the confirmat screw and the numeric model of office furniture assembled with the confirmat screw. It turned out that corner assembly models with the confirmat screw produce firmly fastened assemblies. The deformation of the assembly, as well as of elements to be assembled, represents the rigidity of the construction, which depends on the element geometry after deformation and material properties. The force applied on the screw contributes to its shear loading. When designing and constructing furniture with corner joints, it is important to take into account that material rigidity properties and the flexibility coefficient are characteristic of the angled plane assembly.

Smardzewski and Klos (2011) determined the values of the substitute linear elasticity module in corner joints with dowels subjected to pressure and tension testing. The joint deflection was also tested, and alternative models were made. The research was conducted on the angled plane assemblies with dowels made of solid beech wood with the dimensions of $\varnothing 8 \mathrm{~mm} \times 32 \mathrm{~mm}$. The specimens were made of $16 \mathrm{~mm}$ particleboard. The 
values of numeric calculations obtained from the models truly represent the shape of the tested joints, which are significantly lower than laboratory measurement results. On the other hand, the comparison of the calculation results obtained from models containing nods with substitute linear elasticity modules and the empirical results shows that they are mostly somewhat higher.

Eren and Eckelman (1998) figured out that joint strength and the number of joint components had a correlation. They explained that there are significant differences in strength from board to board. Zhang and Eckelman (1993) analyzed the rational design of multidowel corner joints in $19 \mathrm{~mm}$-thick particleboard case construction. Their results indicated that maximum strength was obtained when the distance between the dowels was at least $76 \mathrm{~mm}$.

Žulj et al. (2015) researched into the angled plane L assembly made of MDF with the density of $0.826 \mathrm{~g} /$ $\mathrm{m}^{3}, 18 \mathrm{~mm}$ thick and melamine faced. The boards were assembled with dowels, wood biscuits, the Minifix hardware and Tofix hardware. The bending moment was highest in the dowel joint $(34.87 \mathrm{Nm})$, then in the wood biscuit joint $(32.34 \mathrm{Nm})$ and the Minifix hardware $(20.35 \mathrm{Nm})$. The lowest value was recorded in connections with the Tofix hardware (14.85 Nm). Tofix is also the weakest joint, whose average bending moment is 2.4 times lower than the one of the dowel joint.

Župčić et al. (2012) researched into the strength of angled plane L assemblies made of particleboard (with the average density of $0.63 \mathrm{~g} / \mathrm{m}^{3}$ ) connected with the bolt with the turning pin, wood biscuit dowel, screw and confirmat screw. As research results show, the highest bending moment values are those in assem- blies with the confirmat and screw, and the lowest in assemblies with the bolt with the turning pin. The glued joint with dowels and biscuits exhibits higher bending moment values in relation to the decomposable joint with the bolt with the turning pin because of the adhesive, which reduces the delamination of the particleboard, increasing thus joint strength.

The type of the selected assembly or connecting element significantly impacts bending moment values and therefore the strength of storage furniture.

The board type, the storage furniture is made of, is not only an important strength factor of such furniture, but also an important factor regarding the price of the future product. Due to larger overall dimensions of such furniture, construction rigidity and decomposable assembly are required. Therefore, the study aimed at researching into the impact of the board type (particleboard and MDF) and the hardware that connects elements on assembly strength.

\section{MATERIALS AND METHODS 2. MATERIJALI I METODE}

\subsection{Making specimen samples}

2.1. Izrada uzoraka

The research was conducted at the Faculty of Forestry, University of Zagreb. The tested specimens had the dimensions of $100 \mathrm{~mm} \times 100 \mathrm{~mm} \times 100 \mathrm{~mm}$ (angled plane assembly, L assemblies) and the specimens consisted of two elements of different dimensions, one of which had the dimensions of $100 \mathrm{~mm} \times$ $100 \mathrm{~mm} \times 18 \mathrm{~mm}$ and the other of $100 \mathrm{~mm} \times 82 \mathrm{~mm} \times$ $18 \mathrm{~mm}$, connected into the L assembly. The specimens

Table 1 Marks of specimens used in research

Tablica 1. Oznake uzoraka obuhvaćenih istraživanjem

\begin{tabular}{|c|l|}
\hline $\begin{array}{c}\text { Specimen mark } \\
\text { Oznaka uzorka }\end{array}$ & Specimen description / Opis uzorka \\
\hline CO-IT & $\begin{array}{l}\text { Specimen made of particleboard and connected with Confirmat screw } \\
\text { uzorak izrađen od iverice povezan confirmat vijkom }\end{array}$ \\
\hline CO-MDF & $\begin{array}{l}\text { Specimen made of MDF and connected with Confirmat screw } \\
\text { uzorak izrađen od MDF ploče povezan confirmat vijkom }\end{array}$ \\
\hline MF-IT & $\begin{array}{l}\text { Specimen made of particleboard and connected with Minifix hardware } \\
\text { uzorak izrađen od iverice povezan minifix okovom }\end{array}$ \\
\hline MF-MDF & $\begin{array}{l}\text { Specimen made of MDF and connected with Minifix hardware } \\
\text { uzorak izrađen od MDF ploče povezan minifix okovom }\end{array}$ \\
\hline MAF-IT & $\begin{array}{l}\text { Specimen made of particleboard and connected with Maxifix hardware } \\
\text { uzorak izrađen od iverice povezan maxifix okovom }\end{array}$ \\
\hline MAF-MDF & $\begin{array}{l}\text { Specimen made of MDF and connected with Maxifix hardware } \\
\text { uzorak izrađen od MDF ploče povezan maxifix okovom }\end{array}$ \\
\hline STF-IT & $\begin{array}{l}\text { Specimen made of particleboard and connected with Stablofix hardware } \\
\text { uzorak izrađen od iverice povezan stablofix okovom }\end{array}$ \\
\hline STF-MDF & $\begin{array}{l}\text { Specimen made of MDF and connected with Stablofix hardware } \\
\text { uzorak izrađen od MDF ploče povezan stablofix okovom }\end{array}$ \\
\hline RV-IT & $\begin{array}{l}\text { Specimen made of particleboard and connected with RV hardware } \\
\text { uzorak izrađen od iverice povezan RV okovom }\end{array}$ \\
\hline RV-MDF & $\begin{array}{l}\text { Specimen made of MDF and connected with RV hardware } \\
\text { uzorak izrađen od MDF ploče povezan RV okovom }\end{array}$ \\
\hline S32-IT & $\begin{array}{l}\text { Specimen made of particleboard and connected with Solo 32 hardware } \\
\text { uzorak izrađen od iverice povezan okovom solo 32 }\end{array}$ \\
\hline S32-MDF & $\begin{array}{l}\text { Specimen made of MDF and connected with Solo 32 hardware } \\
\text { uzorak izrađen od MDF ploče povezan okovom solo 32 }\end{array}$ \\
\hline &
\end{tabular}


were assembled by a fitting without any adhesive applied. Materials used for the research were an improved $18 \mathrm{~mm}$ thick particleboard and an improved $18 \mathrm{~mm}$ thick MDF. The boards were of an unknown manufacturer; the internal bond (IB) for the MDF board was $0.309 \mathrm{~N} / \mathrm{mm}^{2}$ and for the particleboard it was $0.358 \mathrm{~N} /$
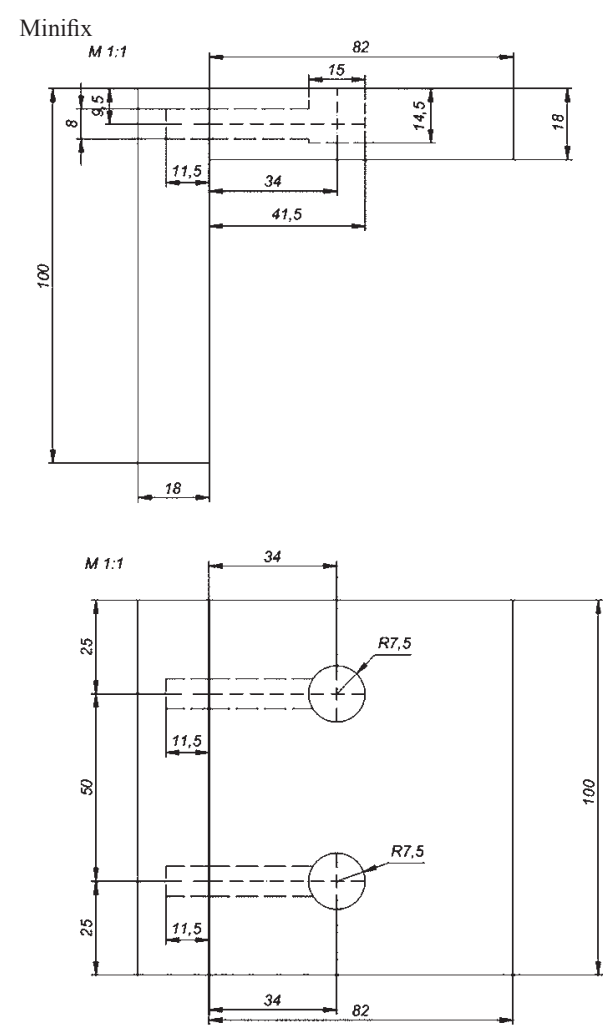

Solo 32
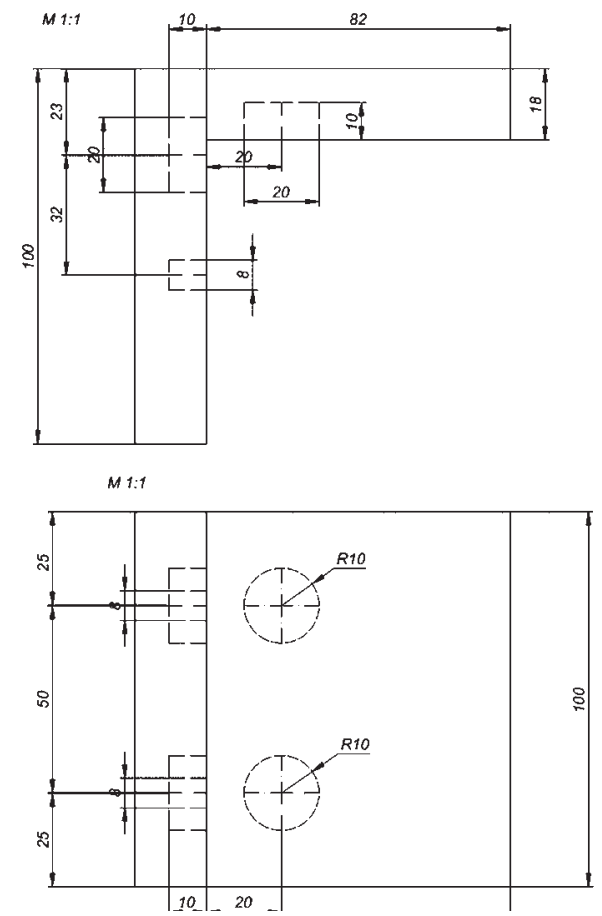

$\mathrm{mm}^{2}$. Altogether 120 specimens were made, 20 series for six hardware types (Minifx, Stablofix, Maxifix, Solo 32, RV, Confirmat) with ten specimens of the particleboard and ten of the MDF for each of the six hardware types (Table 1). Both boards were melamine faced with the edges left uncoated. The examined hard-

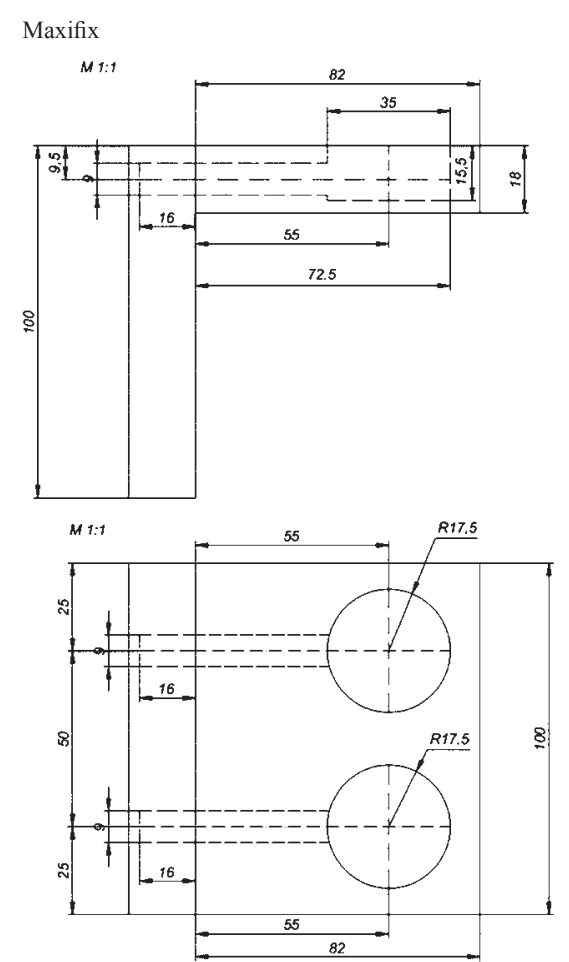

Stablofix
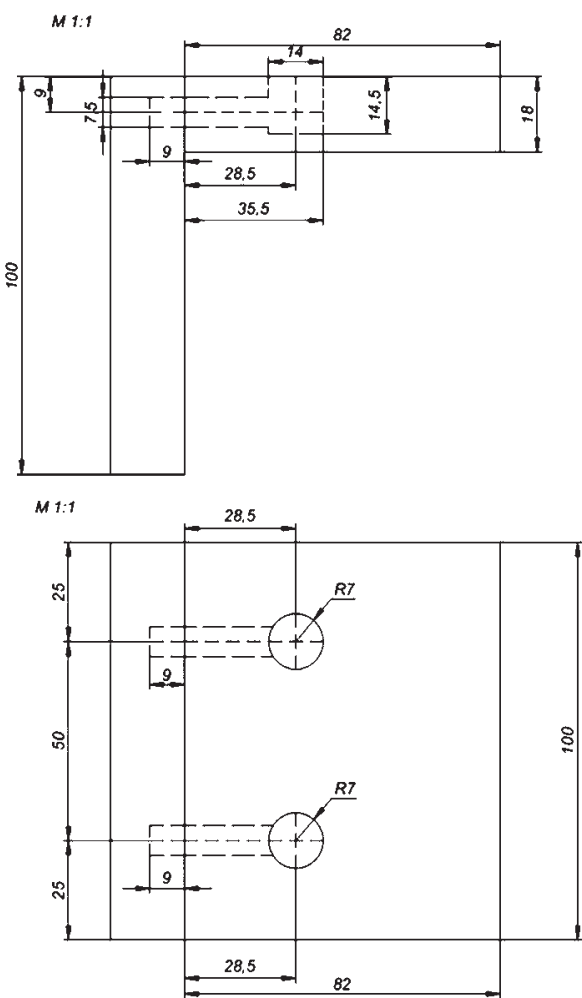

Figure 1 Drawing and layout of $\mathrm{L}$ assembly for six hardware types Slika 1. Nacrt i tlocrt L-sastava za šest tipova okova 

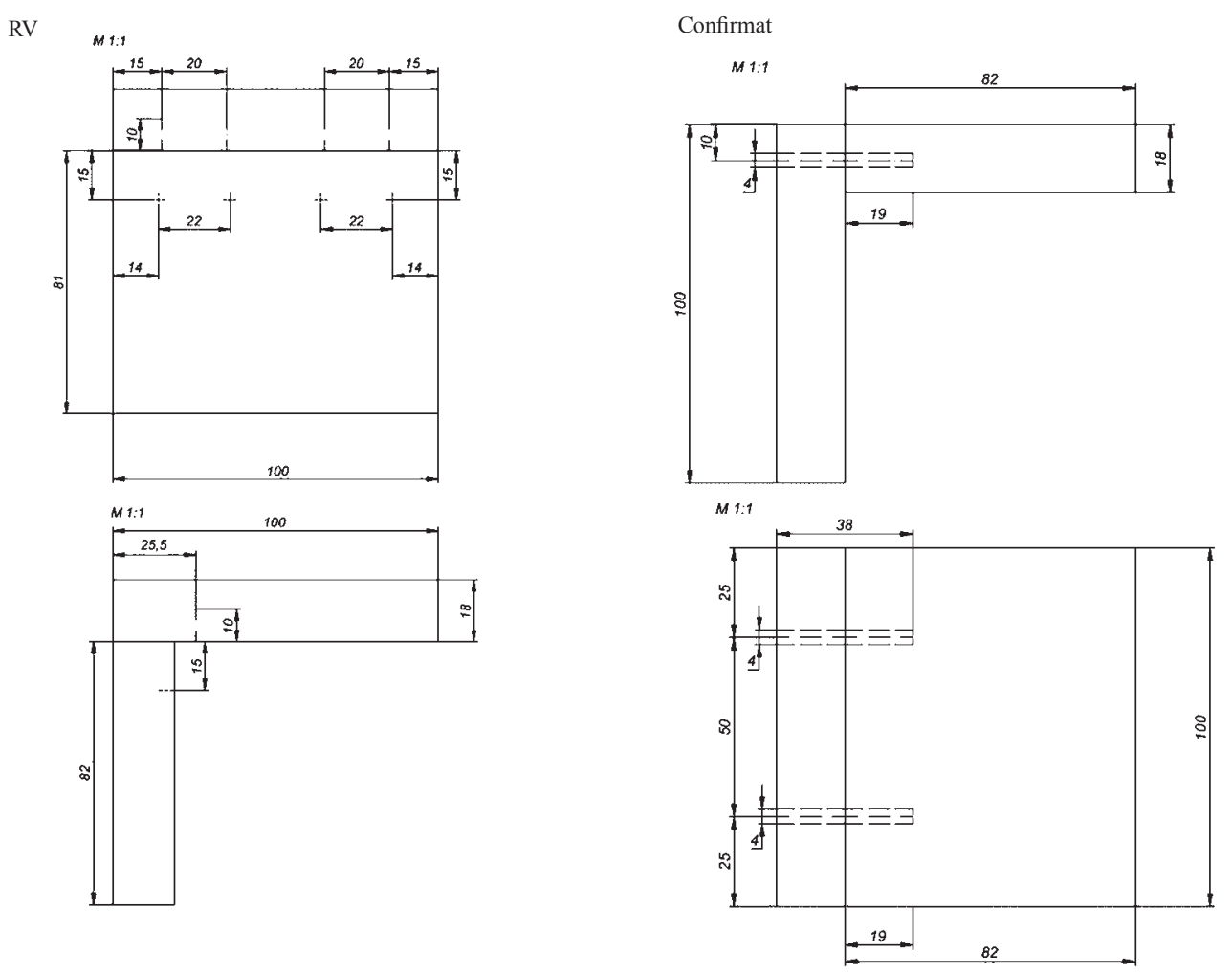

Figure 1 Drawing and layout of L assembly for six hardware types

Slika 1. Nacrt i tlocrt L-sastava za šest tipova okova

ware belonged to the product range of the Häfelle GmbH \& Co KG Company, its Zagreb branch. Both board types used for the research originate from a regular sale and were of an unknown manufacturer.

The boards were conditioned at $(23 \pm 2){ }^{\circ} \mathrm{C}$ and $(50 \pm 5) \%$ relative air humidity for twenty days in the climatic chamber in the Furniture Testing Laboratory, and then the required dimensions were cut. After the cutting, holes were drilled on the elements depending on the hardware applied (Figure 1) and L specimens were assembled in the workshop of the Faculty of Forestry.

The average moisture content was determined by HRN EN 322:2003 and it was $7.50 \%$ for the particleboard and $7.41 \%$ for the MDF board. Density was also determined on the same probes. The average density, determined by HRN EN 323:2008, of the improved particleboard was $0.69 \mathrm{~g} / \mathrm{cm}^{3}$ and $0.86 \mathrm{~g} / \mathrm{cm}^{3}$ of the improved MDF.

\subsection{Testing method}

2.2. Metoda ispitivanja

The assembled specimens were conditioned for 25 days (the samples were not assembled under laboratory conditions and were again conditioned) and then tested on the universal testing machine. These assembled specimens were tested on a computer-aided Shimadzu AG-X universal testing machine. The displacement speed during the testing was $5 \mathrm{~mm} / \mathrm{min}$. The specimens were tested with the articulation gripping jaws, which enabled their precise positioning (Figure 2). A total of 120 specimens were used for the testing, all of them properly assembled with no visible defects or other damage on the board.
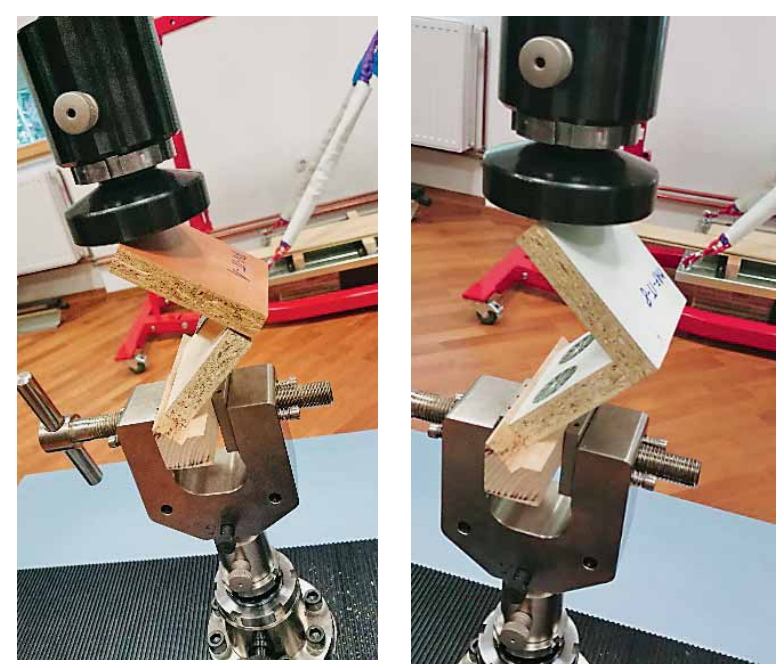

Figure 2 Testing method of bending moment for: a) RV hardware; b) Maxfix hardware

Slika 2. Način ispitivanja momenta savijanja: a) okov RV; b) okov maxifix

\section{RESULTS AND DISCUSSION} 3. REZULTATI I RASPRAVA

The research results (Table 2, 3, 4 and Figure 3) show that the board and hardware type have an impact on both the bending moment of the assembly and its strength (as the parameters are the same for all specimens and no adhesive was applied when assembling). The choice of board type has a statistically significant impact on the joint strength in all hardware types except for S32 specimens. As a result, joints made of MDF exhibit statistically higher bending moment values in all hardware types (except for S32 specimens) 
than the joint made of particleboard. Such results were to be expected as the MDF is of a more homogeneous structure as compared to the particleboard and exhibits different mechanical properties.

The hardware type also has a considerable impact on bending moment or joint strength results in specimens made of particleboard and MDF. The highest bending moment value was recorded in MAF-MDF specimens (Maxifix) made of MDF with the average value of $85.88 \mathrm{Nm}$, while the lowest bending moment value of only $25.40 \mathrm{Nm}$ was recorded in MF-IT specimens (Minifix) made of particleboard. For purposes of the research, $18 \mathrm{~mm}$ thick boards were used as they have adequate thickness for all hardware types. The Maxifix hardware is of a robust construction so that it takes a large portion of the loading in the joint. Besides that, this hardware type may be applied on thicker boards so that it can be assumed that, under such conditions, joint strength would be higher. During the testing, the delamination of the board occurred in all MAF specimens. This points to the fact that wood core plywood, veneered wood panel or solid wood panel (solid across its width and length) would reach better joint strength values with this hardware as they are more resistant to delamination. According to the research of Jivkov and Grbac (2011), samples jointed with a confirmation screw have the highest values of bending moment (33.42 Nm), while samples jointed with Minifix and Rafix have the lowest values of bending moment, 9.75 Nm and 6.02 Nm, respectively. The distribution is similar as in this research.

Different hardware types installed in the MDF exhibit a statistically significant difference in the bending moment except for RV and CO specimens and STF and MF specimens. MAF specimens (MDF) have 2.4 higher values as compared to STF specimens, indicating that the choice of the hardware type has a large impact on the assembly strength when assembling storage furniture. IT specimens show a somewhat smaller ratio of 2.1 times (between MAF-IT and MF-IT).
In case of $\mathrm{L}$ assemblies, the aesthetic of the assembly matters as well, besides its strength. All hardware types used for this research are on the inner side of the joint except for the confirmat screw. The confirmat screw is therefore the least acceptable aesthetical$\mathrm{ly}$, as it is visible on the furniture lateral side. Maxifix is a robust and big system that may be hidden beneath cover caps and shows the best results for the boards tested. It may be installed in boards of larger dimensions and, therefore, proves to be the most acceptable. The strength of the same assembly on the various plate materials may deviate significantly. These deviations are even greater with different structural assemblies on the same material (Tkalec and Prekrat 2000).

Besides the strength and aesthetic of the joint, there are other factors that need to be considered such as hardware complexity for installation, its price, market availability, etc. All these factors influence the functionality, safety, reliability and aesthetic of furniture and its technological and financial availability to the customer.

Figure 4 shows load-displacement curve. Force increases in accordance with displacement up to its maximum value and starts decreasing thereafter. The increase in force to the maximum value (for all assemblies) is similar. However, its decrease differs and mostly depends on the hardware type. In MF, MAF and STF specimens, due to force, the following phenomena occur: board delamination in the hardware installation zone, screw head passing through the board in $\mathrm{CO}$ specimens, screw withdrawal from the board in RV hardwares, hardware bending in S32 specimens. In case of S32 hardware, the board type has no statistically significant impact on joint strength due to the specific nature of such hardware and hardware bending when tested. Screws that fasten the hardware to the boards and the fitting itself take joint strain (in $\mathrm{CO}, \mathrm{RV}$ and S32). Therefore, no joint fracture occurs, but rather an easy screw withdrawal from the board and hardware bending.

Table 2 Descriptive statistics of bending moment $(\mathrm{Nm})$ depending on board and hardware type

Tablica 2. Deskriptivna statistika momenta savijanja ( $\mathrm{Nm})$ u ovisnosti o vrsti ploče i tipu okova

\begin{tabular}{|c|c|c|c|c|c|c|c|c|}
\hline $\begin{array}{c}\text { Specimen } \\
\text { Uzorak }\end{array}$ & $\begin{array}{c}\text { Number of } \\
\text { specimens, } \boldsymbol{N} \\
\text { Broj uzoraka, } N\end{array}$ & $\begin{array}{c}\text { Average } \\
\text { Srednja } \\
\text { vrijednost }\end{array}$ & $\begin{array}{c}\text { Standard deviation } \\
\text { Standardna devijacija }\end{array}$ & Minimum & Maximum & Q25 & Median & Q75 \\
\hline CO-IT & 10 & 40.38 & 3.46 & 35.21 & 45.47 & 36.65 & 41.24 & 42.42 \\
\hline CO-MDF & 10 & 64.24 & 5.21 & 56.55 & 72.22 & 61.15 & 63.78 & 66.00 \\
\hline MAF-IT & 10 & 52.91 & 7.62 & 34.29 & 59.95 & 49.18 & 54.35 & 58.78 \\
\hline MAF-MDF & 10 & 85.88 & 9.22 & 72.31 & 99.63 & 81.32 & 85.07 & 92.92 \\
\hline MF-IT & 10 & 25.40 & 2.56 & 22.31 & 28.99 & 22.48 & 25.59 & 27.07 \\
\hline MF-MDF & 10 & 43.04 & 2.22 & 40.57 & 47.81 & 41.18 & 42.56 & 43.88 \\
\hline STF-IT & 10 & 27.29 & 2.06 & 23.39 & 31.18 & 26.21 & 27.33 & 27.51 \\
\hline STF-MDF & 10 & 36.68 & 3.18 & 31.61 & 41.23 & 34.91 & 37.53 & 38.92 \\
\hline RV-IT & 10 & 48.73 & 3.65 & 41.31 & 53.37 & 47.93 & 49.16 & 50.94 \\
\hline RV-MDF & 10 & 63.34 & 3.34 & 59.21 & 69.42 & 60.20 & 63.38 & 65.35 \\
\hline S32-IT & 10 & 50.32 & 1.23 & 48.11 & 51.90 & 49.51 & 50.21 & 51.41 \\
\hline S32-MDF & 10 & 52.16 & 1.54 & 48.98 & 53.76 & 50.81 & 52.95 & 53.21 \\
\hline All specimens & 120 & 49.20 & 16.72 & 22.31 & 99.63 & 38.00 & 49.24 & 58.99 \\
svi uzorci & & & & & & & \\
\hline
\end{tabular}


... Župčić, Žulj, Kamerman, Grbac, Vlaović: Research into Corner L Separable Assemblies...

Table 3 Statistical testing of variance for all samples together

Tablica 3. Statističko testiranje varijance za sve uzorke

\begin{tabular}{|c|c|c|c|c|c|c|c|c|}
\hline \multirow{2}{*}{ Variable / Varijabla } & \multicolumn{8}{|c|}{$\begin{array}{l}\text { Levene Test of Homogeneity of Variances / Leveneov test značajnosti varijanci } \\
\text { Marked effects are significant at } p<0.05000 \text { / označeni su efekti značajni pri p<0.05000 }\end{array}$} \\
\hline & $\begin{array}{c}\text { SS } \\
\text { Effect }\end{array}$ & $\begin{array}{c}d f \\
\text { Effect }\end{array}$ & $\begin{array}{c}M S \\
\text { Effect }\end{array}$ & $\begin{array}{l}\text { SS } \\
\text { Error }\end{array}$ & $\begin{array}{l}d f \\
\text { Error }\end{array}$ & $\begin{array}{l}M S \\
\text { Error }\end{array}$ & $F$ & $p$ \\
\hline $\begin{array}{l}\text { Bending moment, } \mathrm{Nm} \\
\text { moment savijanja, } \mathrm{Nm}\end{array}$ & 378.4366 & 11 & 34.40332 & 749.0131 & 108 & 6.935306 & 4.960606 & 0.000003 \\
\hline
\end{tabular}

Table 4 Post-hoc test for all samples

Tablica 4. Post-hoc test za sve uzorke

\begin{tabular}{|c|c|c|c|c|c|c|c|c|c|c|c|c|}
\hline \multirow{2}{*}{$\begin{array}{l}\text { Specimen } \\
\text { Uzorak }\end{array}$} & \multicolumn{12}{|c|}{$\begin{array}{l}\text { Scheffe Test; Variable: Bending moment, } \mathbf{N m} \text { / Scheffe tes varijable: moment savijanja, } \mathrm{Nm} \\
\text { Marked differences are significant at } \boldsymbol{p}<\mathbf{0 . 0 5 0 0 0} \text { / označeni su efekti značajni pri } p<0.05000\end{array}$} \\
\hline & $\begin{array}{c}(1) \\
M=40.382\end{array}$ & $\begin{array}{c}(2) \\
\mathrm{M}=64.240\end{array}$ & $\begin{array}{c}(3) \\
\mathrm{M}=52.919\end{array}$ & $\begin{array}{c}(4) \\
M=85.880\end{array}$ & $\begin{array}{c}(5) \\
M=25.405\end{array}$ & $\begin{array}{c}(6) \\
M=43.042\end{array}$ & $\begin{array}{c}(7) \\
M=27.294\end{array}$ & $\begin{array}{c}(8) \\
M=36.686\end{array}$ & $\begin{array}{c}(9) \\
\mathrm{M}=48.738\end{array}$ & $\begin{array}{c}(10) \\
\mathrm{M}=63.350\end{array}$ & $\begin{array}{c}(11) \\
\mathrm{M}=50.324\end{array}$ & $\begin{array}{c}(12) \\
\mathrm{M}=52.165\end{array}$ \\
\hline CO-IT (1) & & 0.000000 & 0.000224 & 0.000000 & 0.000002 & 0.998954 & 0.000080 & 0,981340 & 0,106229 & 0,000000 & 0,015308 & 0.000857 \\
\hline CO-MDF (2) & 0.000000 & & 0.001867 & 0.000000 & 0.000000 & 0.000000 & 0.000000 & 0.000000 & 0.000001 & 1.000000 & 0.000016 & 0.000514 \\
\hline MAF-IT (3) & 0.000224 & 0.001867 & & 0.000000 & 0.000000 & 0.016755 & 0.000000 & 0.000000 & 0.952237 & 0.007558 & 0.999172 & 1.000000 \\
\hline MAF-MDF (4) & 0.000000 & 0.000000 & 0.000000 & & 0.000000 & 0.000000 & 0.000000 & 0.000000 & 0.000000 & 0.000000 & 0.000000 & 0.000000 \\
\hline MF-IT (5) & 0.000002 & 0.000000 & 0.000000 & 0.000000 & & 0.000000 & 0.99964 & 0.001995 & 0.000000 & 0.000000 & 0.000000 & 0.000000 \\
\hline MF-MDF (6) & 0.998954 & 0.000000 & 0.016755 & 0.000000 & 0.000000 & & 0.000000 & 0.514195 & 0.690636 & 0.000000 & 0.281478 & 0,044666 \\
\hline STF-IT (7) & 0.000080 & 0.000000 & 0.000000 & 0.000000 & 0.999964 & 0.000000 & & 0.031923 & 0.000000 & 0.000000 & 0.000000 & 0.000000 \\
\hline STF-MDF (8) & 0.981340 & 0.000000 & 0.000000 & 0.000000 & 0.001995 & 0.514195 & 0.031923 & & 0.000536 & 0.000000 & 0.000027 & 0.000001 \\
\hline RV-IT (9) & 0.106229 & 0.000001 & 0.952237 & 0.000000 & 0.000000 & 0.690636 & 0.000000 & 0.000536 & & 0.000004 & 0.999994 & 0.989972 \\
\hline RV-MDF (10) & 0.000000 & 1.000000 & 0.007558 & 0.000000 & 0.000000 & 0.000000 & 0.000000 & 0.000000 & 0.000004 & & 0.000090 & 0.002333 \\
\hline S32-IT (11) & 0.015308 & 0.000016 & 0.999172 & 0.000000 & 0.000000 & 0.281478 & 0.000000 & 0.000027 & 0.999994 & 0.000090 & & 0.999972 \\
\hline S32-MDF (12) & 0.000857 & 0.000514 & 1.000000 & 0.000000 & 0.000000 & 0.044666 & 0.000000 & 0.000001 & 0.989972 & 0.002333 & 0.999972 & \\
\hline
\end{tabular}

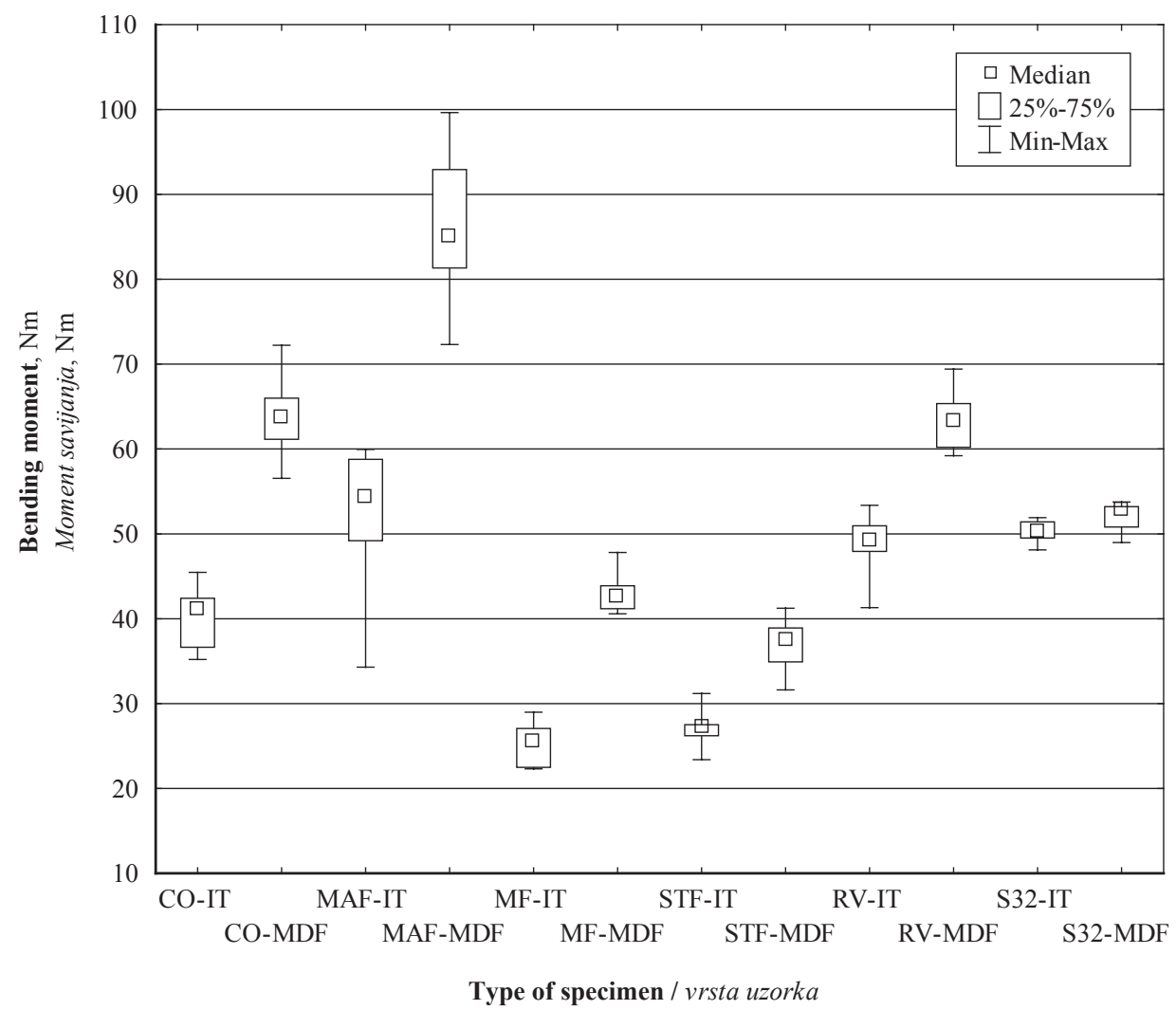

Figure 3 Impact of board and hardware type on bending moment

Slika 3. Utjecaj vrste ploče i tipa okova na moment savijanja 
Župčić, Žulj, Kamerman, Grbac, Vlaović: Research into Corner L Separable Assemblies... ...

CO - IT

$\mathbf{F}_{\text {max }}=352.49 \mathrm{~N}$

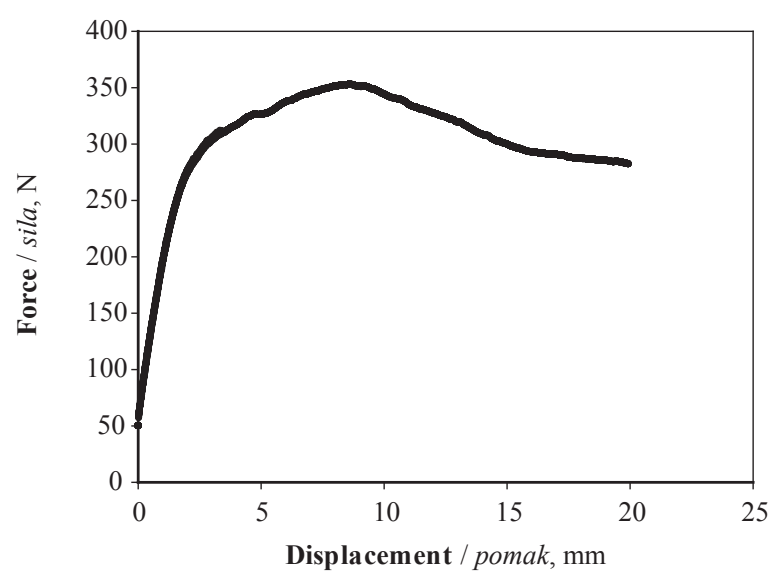

MAF - IT

$\mathbf{F}_{\max }=464.75 \mathrm{~N}$

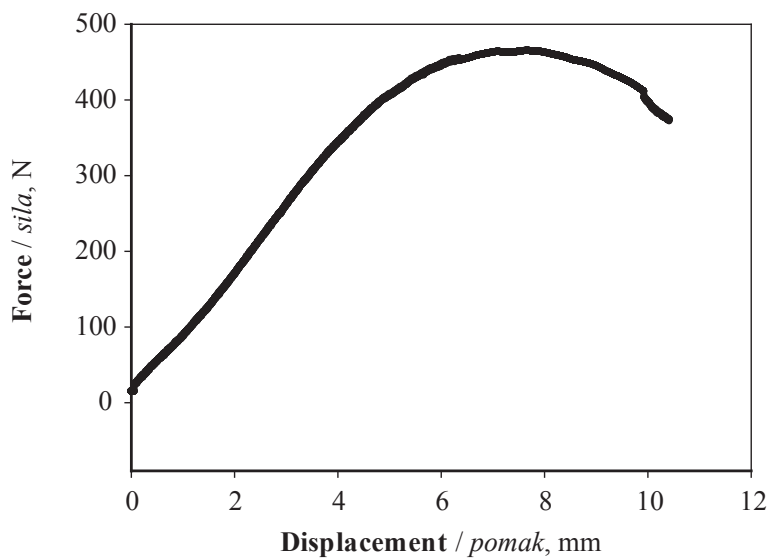

MF - IT

$\mathbf{F}_{\mathbf{m a x}}=224.73 \mathrm{~N}$

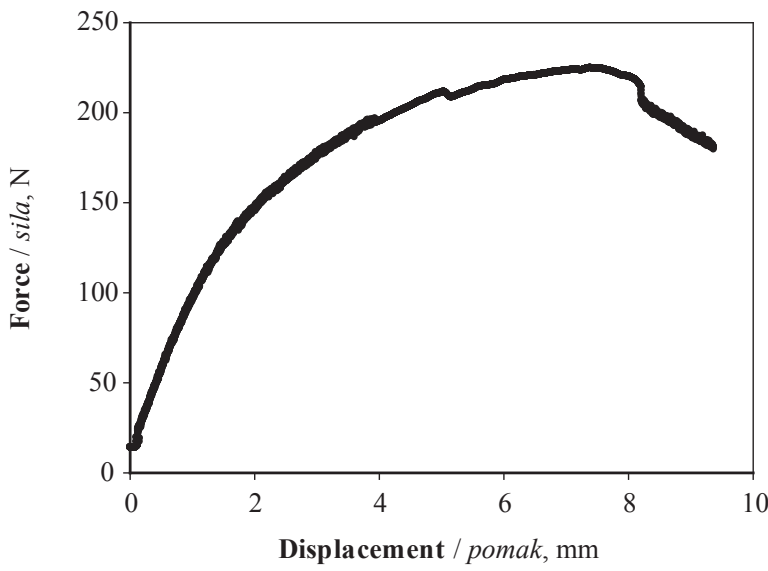

CO - MDF

$\mathbf{F}_{\mathbf{m a x}}=560.19 \mathrm{~N}$

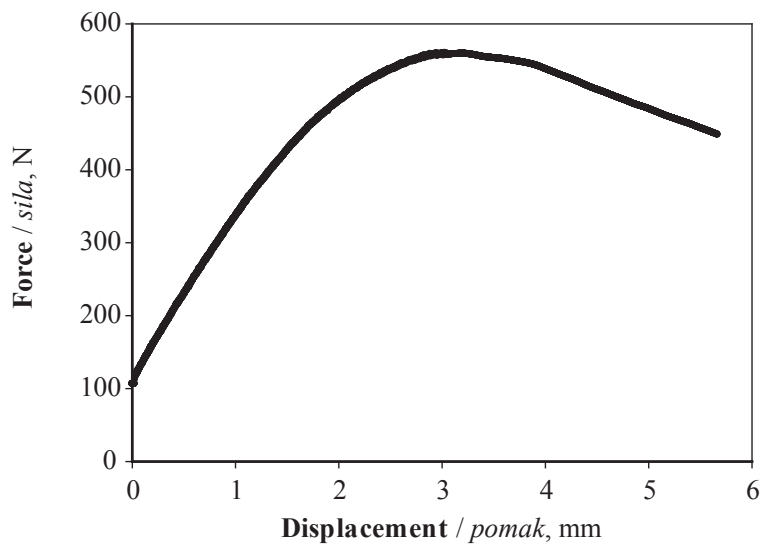

MAF - MDF

$\mathbf{F}_{\mathbf{m a x}}=772.38 \mathrm{~N}$

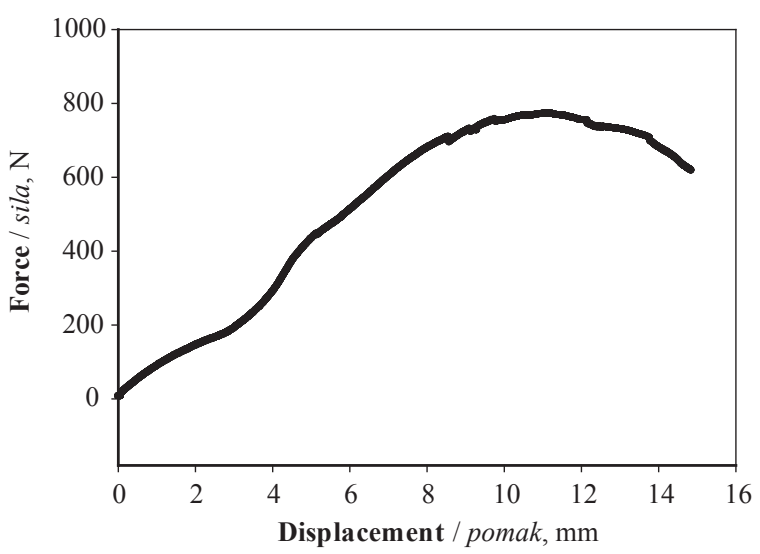

MF - MDF

$\mathbf{F}_{\mathbf{m a x}}=370.77 \mathrm{~N}$

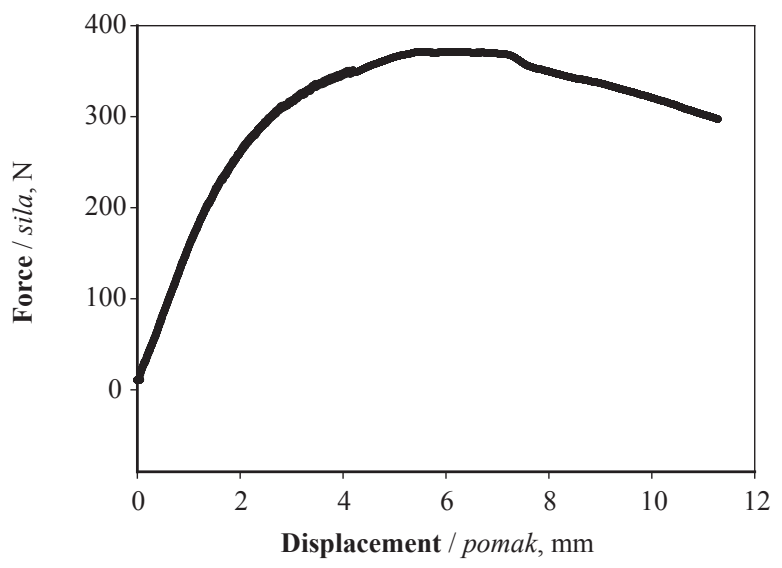

Figure 4 Load-displacement curve (maximum value) for given hardware and board types

Slika 4. Raspodjela sile ovisno o pomaku (najveća vrijednost) za određeni tip okova i ploča (dijagram loma) 
.. Župčić, Žulj, Kamerman, Grbac, Vlaović: Research into Corner L Separable Assemblies...

RV - IT

$\mathbf{F}_{\max }=414.34 \mathrm{~N}$

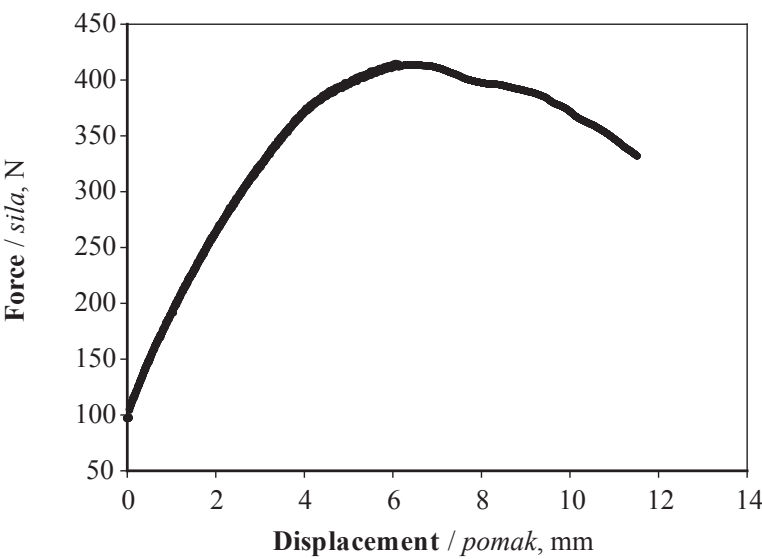

S32 - IT

$\mathbf{F}_{\max }=402.57 \mathrm{~N}$

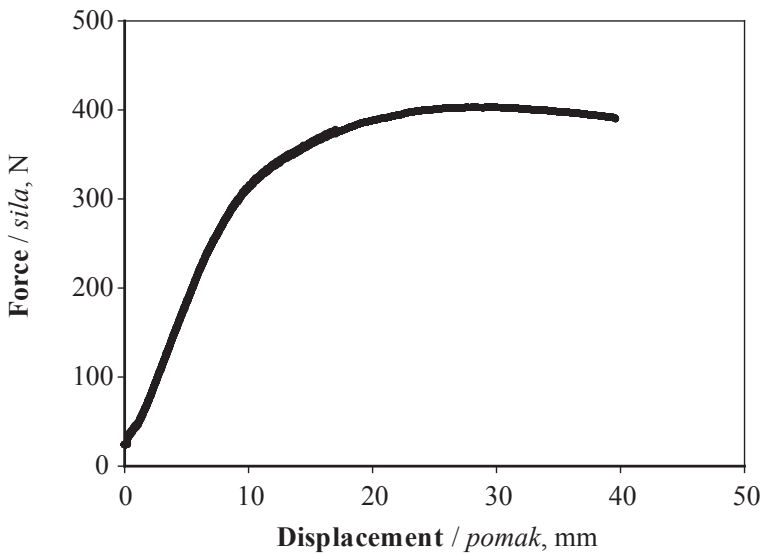

STF - IT

$\mathbf{F}_{\mathbf{m a x}}=241.74 \mathrm{~N}$

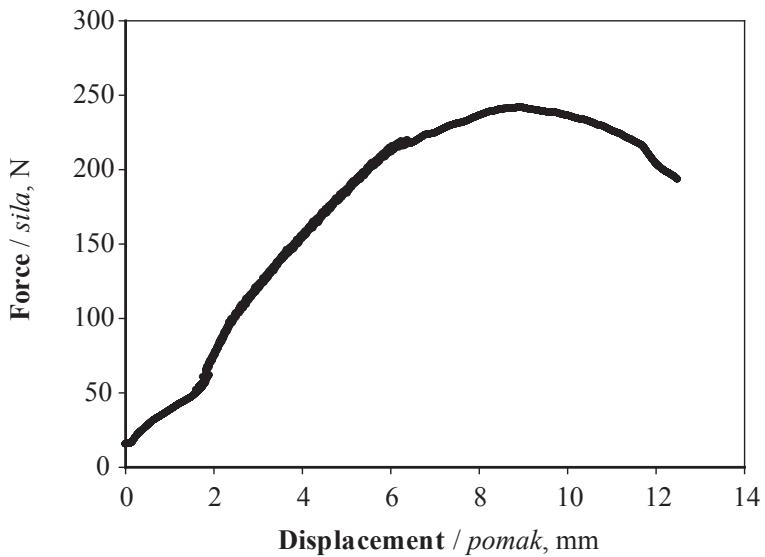

RV - MDF

$\mathbf{F}_{\max }=538.16 \mathrm{~N}$

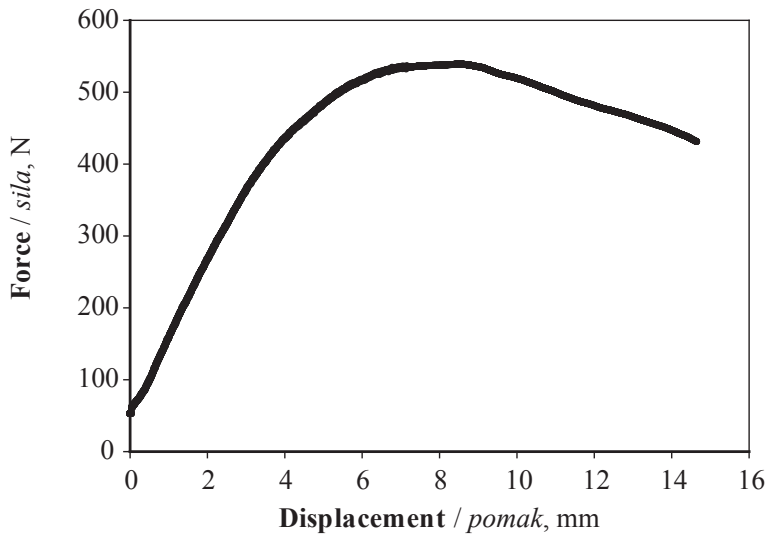

S32 - MDF

$\mathbf{F}_{\mathbf{m a x}}=416.83 \mathrm{~N}$

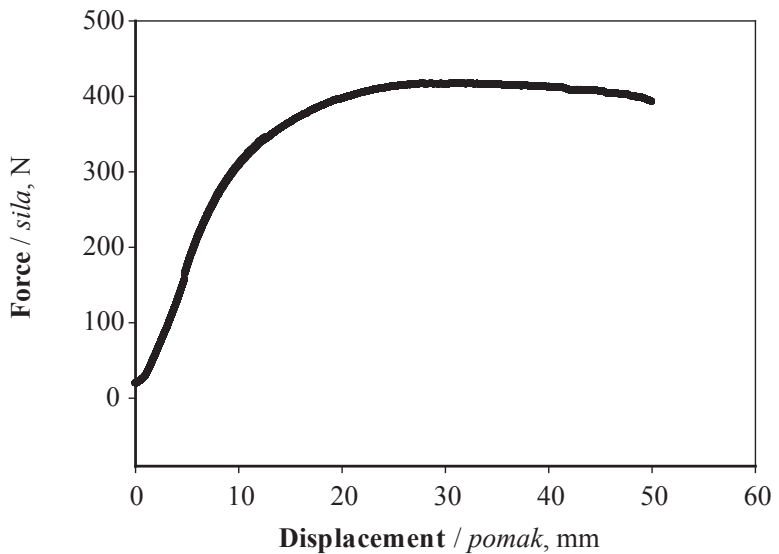

STF - MDF

$\mathbf{F}_{\max }=319.63 \mathrm{~N}$

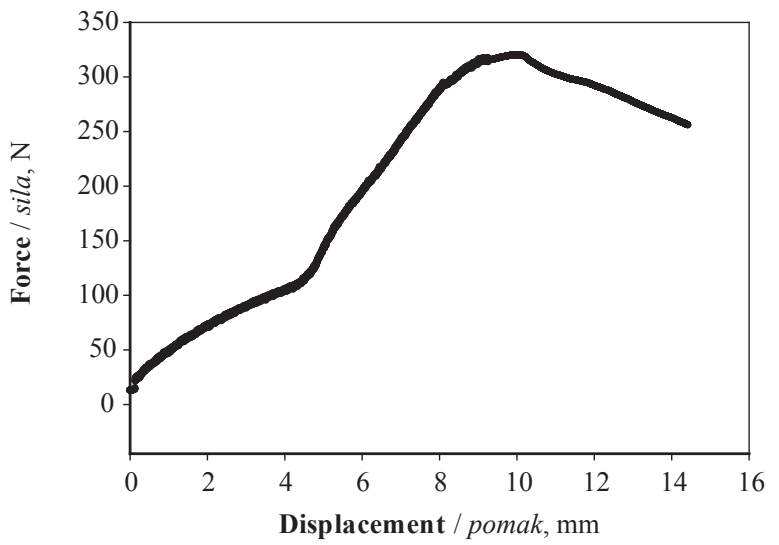

Figure 4 Load-displacement curve (maximum value) for given hardware and board types (continuation)

Slika 4. Raspodjela sile ovisno o pomaku (najveća vrijednost) za određeni tip okova i ploča (dijagram loma) (nastavak) 
It may be assumed that edge processing (with a mini ABS tape for example) would increase the strength of the assembly in MAF, MF and STF. The ABS tape would strengthen the board edge increasing the bending moment or the strength of the joint. The visible edge of the particleboard is always coated so that attention should be given to the hardware orientation with regard to the processed edge (the side or the top or the bottom). It can therefore be assumed that an installed hardware in a specific piece of furniture would exhibit even higher values (except for furniture made of lacquered MDF).

\section{CONCLUSIONS}

4. ZAKLJUČAK

The board type has a statistically significant impact on the strength of assemblies (except for S32 specimens). The hardware installed in the improved MDF has statistically higher bending moment values as compared to the hardware installed in the improved particleboard (except for S32 specimens).

The hardware type has a significant impact on the maximum bending moment or assembly strength. In specimens made of particleboard and MDF, there are statistically significant differences as shown in Table 4. Depending on the hardware type, the average maximum bending moment increases by over two times independent of the board type, which constitutes a significant difference as a furniture strength indicator. Therefore, a proper hardware choice plays an important role in determining the decomposable construction of future storage furniture.

Joint strength in S32 specimens depends on the force required for hardware bending so that the board type has no statistically significant impact.

When testing, the assembly fracture also depends on the hardware type. Board delamination is characteristic for most hardwares except for assemblies with the confirmat screw and the RV hardware fastened by screws.

The Maxifix hardware exhibited the best results of all tested hardware with regard to the bending moment independent of the board type, it is acceptable aesthetically as it is installed from the inner side of the assembly and enables the application on boards with the thickness of over $18 \mathrm{~mm}$.

\section{REFERENCES}

5. LITERATURA

1. Atar, M.; Ozcifci, A., 2007: The effects of screw and back panels on the strength of corner joints in case furniture. Material and Designs, 29: 519-525. https://doi.org/10.1016/j.matdes.2007.01.015.

2. Ayrilmis, N.; Akbulut, T., 2018: Screw withdrawal resistance and surface soundness of three-layer fiberboard having coarse fibers in core layer. Drvna industrija, 69(4): 379-385. https://doi.org/10.5552/drind.2018.1804.

3. Eren, S.; Eckelman, C. A., 1998: Edge breaking strength of wood composites. Holz als Roh-und Werkstoff, 56(2): 115-120.

4. Jivkov, V.; Grbac, I., 2011: Influence of the cyclic loading on bending strength of different end corner joints made of MDF. 22nd International conference: Wood is good - EU preaccession challenges of the sector. Grbac, I. (ed.), University of Zagreb, Faculty of Forestry, Zagreb, Croatia, pp. 59-66.

5. Kureli, I.; Altinok, M., 2011: Determination of mehanical performances of the portable fasteners used on case furniture joints. African Journal of Agricultural Research, 6(21): 4839-4901.

6. Smardzewski, J.; Ożarska, B., 2005: Rigidity of cabinet furniture with semi-rigid joints of the confirmat type. Electronic Journal of Polish Agricurtural Universities Wood Technology, 8 (2).

7. Smardzewski, J.; Klos, R., 2011: Modeling of joint substitutive rigidity of board elements. Forestry and Wood Technology, 73: 7-15. https://doi.org/10.3906/tar-1406-92.

8. Tkalec, S.; Prekrat, S., 2000: Konstrukcije proizvoda od drva 1. Šumarski fakultet Sveučilišta u Zagrebu, Zagreb.

9. Vassiliou, V.; Barboutis, I., 2009: Bending strength of furniture corner joints constructed with insert fittings. Annals of Warsaw University of Life Sciences - Forestry and wood technology, 67: 268-274.

10. Zhang, J.; Eckelman, C. A., 1993: Rational design of multi dowel corner joints in case construction. Forest Product Journal, 43(11/12): 52-58.

11. Žulj, I.; Župčić, I.; Grbac, I.; Trupković, M., 2015. Research of strength of corner L joints 26th International Conference on wood science and technology. Grbac, I. (ed.), University of Zagreb, Faculty of Forestry, Zagreb, pp. 221-226.

12. Župčić, I.; Grbac, I.; Bogner, A.; Hadžić, D., 2012: Research corner joints in corpus furniture. 23rd International conference: Wood is good - with knowledge and technology to a competitive forestry and wood technology sector. University of Zagreb, Faculty of Forestry, Zagreb, Croatia, pp. 229-235.

13. Yerlikaya, N., 2012: Effects of glass - fiber composite, dowel and minifix fasteners on the failure load of corner joints in particelboard case-type furniture. Materials and Designs 39: 63-71.

https://doi.org/10.1016/j.matdes.2012.02.024.

14. *** HRN EN 322, 2003: Wood-based Boards - Determining Wood Content.

15. *** HRN EN 323, 2008: Wood-based Boards - Determining Density.

\section{Corresponding address:}

\section{IVAN ŽULJ}

University of Zagreb

Faculty of Forestry

Svetošimunska 25

10000 Zagreb, CROATIA

e-mail: izulj@sumfak.hr 